\title{
Potato Germplasm Enhancement Enters the Genomics Era
}

\author{
Paul C. Bethke, Dennis A. Halterman and Shelley H. Jansky * \\ USDA Agricultural Research Service, Vegetable Crops Research Unit, Madison, WI 33003, USA; \\ Paul.Bethke@usda.gov (P.C.B.); Dennis.Halterman@usda.gov (D.A.H.) \\ * Correspondence: shjansky@wisc.edu; Tel.: +1-608-262-8324
}

Received: 26 July 2019; Accepted: 18 September 2019; Published: 23 September 2019

\begin{abstract}
The goal of germplasm enhancement is to introgress traits from wild crop relatives into cultivated material and eventually cultivars. It seeks to restore genetic diversity that has been lost over time or to augment cultivated material with novel alleles that improve parents in breeding programs. This paper discusses potato germplasm enhancement efforts in the past, focusing on effective examples such as disease resistance and processing quality. In addition, it outlines new strategies for enhancement efforts, shifting the focus from evaluating phenotypes to tracking and manipulating specific DNA sequences. In the genomics era, germplasm enhancement will increasingly be focused on identifying and introgressing alleles rather than traits. Alleles will come from a broad pool of genetic resources that include wild species relatives of potato, landraces, cultivated potato itself, and distantly-related species. Genomics tools will greatly increase the efficiency of introgressing multi-genic traits and will make it possible to identify rare alleles and utilize recessive alleles.
\end{abstract}

Keywords: Solanum tuberosum; potato breeding; potato genebank; biotechnology; wild potato species; Solanaceae

\section{Germplasm Enhancement}

Germplasm enhancement is the incorporation of traits from wild crop relatives into cultivated material. In some cases, it seeks to restore genetic diversity that has been lost over time as a result of domestication, migration, disease, and other sources of bottlenecks. In other cases, it introduces novel traits into cultivated germplasm. When successful, germplasm enhancement improves the breeding merits of individuals that carry the introduced trait. Germplasm enhancement consists of three phases. The first identifies germplasm that contains the trait of interest. A trait may be a phenotype or a DNA sequence. Second, that trait or sequence is introduced into cultivated material. Lastly, individuals with the desired trait are identified. These individuals may be new varieties, in the case of genetically-modified or engineered potatoes, but are more likely to be parents used in breeding programs. As described below, genomics tools applied to potato germplasm enhancement are likely to be used in each of these three phases, with the goal of making each more efficient. Genomics tools will also expand the range of donor individuals that can contribute alleles for germplasm enhancement. On their own, however, genomics tools will not be a panacea for potato improvement. They must be partnered with compatible phenotyping methods and accessible germplasm resources if they are to have the greatest effect on potato-breeding progress.

\section{The genetic Base of Cultivated Potato}

Potatoes grown for commercial production worldwide are the descendants of landraces developed in South America. Potato was first domesticated as a diploid crop in the highlands of Southern Peru from a wild progenitor in the Solanum brevicaule complex [1,2]. Polyploidy is common in both wild 
and cultivated potato, likely due to the widespread occurrence (but low frequency) of mutations that result in $2 n$ gametes (gametes with the sporophytic chromosome number) [3,4]. The union of a $2 n$ egg with a $2 n$ sperm, although a rare event, would create a viable tetraploid. The ability of potato to reproduce asexually allowed newly formed tetraploids to survive until sexual partners became available. Repeated sexual polyploidization of early landrace diploids likely led to Andean tetraploid varieties [5]. After potatoes were domesticated in the Andes of equatorial South America, they were introduced into temperate regions in southern Chile. Consequently, there are two groups of landrace potatoes-Andean and Chilean. Andean potatoes can be diploid, triploid, tetraploid or pentaploid, while most Chilean potatoes are tetraploid [6].

In the potato's native regions, numerous wild relatives grow in close proximity to farmers' fields, and insect-aided cross pollination of cultivated potatoes with each other and with wild relatives is common [7-9]. Amazingly, in a recent study of Solanum germplasm diversity that included 20 diploid wild potato relatives, $73 \%$ of alleles in the wild germplasm were also found in North American cultivars, which are tetraploid [10]. It is also interesting to note that, while wild introgressions appear to be common in cultivated tetraploids, they are rare in cultivated diploids. Only $2 \%$ of genomic regions in diploid landraces contained wild introgressions, but $20 \%$ and $31 \%$ of cultivated tetraploid Andean and Chilean landraces, respectively, contained introgressions from wild relatives. Apparently, the tetraploid condition enhances opportunities for wild introgressions. Grun [11] describes tetraploid Andean potato as a "genetic sponge," capable of absorbing genes through introgressions from the diverse array of wild and cultivated relatives in its surroundings. Thus, cultivated potato at its center of origin in the Peruvian Andes is rich in allelic diversity.

Throughout its history, cultivated potato has experienced severe and repeated selection pressure (Table 1). As is common for most crops, selection by humans during domestication, adaptation to novel growing environments, and disease pressure are thought to have resulted in genetic bottlenecks that have reduced the genetic base of potato. Potatoes were domesticated near the equator under short day conditions and, like local wild potato species, tubers form readily under a 12-h photoperiod [12,13] but not under the long photoperiod typical of the growing season in southern Chile, Europe and North America. Cultivated potato in these regions is considered to be day neutral, with tuber initiation occurring a few weeks after plants emerge from the soil [14]. Tuber initiation is controlled by the StCDF1 gene via the CONSTANS gene [15]. In most cases, StCDF1 haplotypes from North American cultivars have derived their photoperiod adaptation allele from S. microdontum [10]. Solanum microdontum does not appear in cultivar pedigrees, but introgressions have been found on 10 of 12 chromosomes in North American cultivars [10]. This diploid potato relative is native to a region that extends from Bolivia, near the center of potato domestication, to northern Argentina at a latitude of $27^{\circ} \mathrm{S}$. Incorporation and retention of $S$. microdontum germplasm may have been necessary for tuber formation under a long photoperiod as potatoes migrated to southern Chile. This photoperiod adaptation trait was further reinforced after potatoes were brought to Europe by Spanish explorers in the mid- $16^{\text {th }}$ century [16-19]. It has been proposed recently that potatoes growing in Europe acquired de-novo mutations in StCDF1 after the mid-1700s and these were rapidly fixed in European cultivars because of the potential breeding advantage [20].

Outbreaks of disease, particularly the late blight pandemics that began in the 1840s and seed-borne viruses carried in tuber propagules, also exerted strong selection pressure on cultivated potato [21]. Many potato varieties across the globe were lost to late blight in the $19^{\text {th }}$ century [22]. Resistance to late blight was identified in the wild potato relative S. demissum, and interspecies hybrids were used to develop new varieties that carried resistance genes [23,24]. Potato genotypes were also lost due to problems associated with tuber propagation, including virus accumulation, seed storage losses, and loss of fertility [22,25]. 
Table 1. Putative genetic bottlenecks in the domestication and breeding of potato.

\begin{tabular}{ccc}
\hline Trait Selected & Time & Consequence \\
\hline $\begin{array}{c}\text { Domestication traits (large tubers, } \\
\text { short stolons, palatability) }\end{array}$ & $6000 \mathrm{BCE}$ & $\begin{array}{c}\text { A subset of wild germplasm becomes } \\
\text { the foundation for landrace potatoes. }\end{array}$ \\
\hline $\begin{array}{c}\text { Adaptation to long photoperiod in } \\
\text { Southern Chile }\end{array}$ & Pre-Colombian & $\begin{array}{c}\text { A subset of Andean potatoes serves as } \\
\text { the founder of Chilean germplasm. }\end{array}$ \\
\hline $\begin{array}{c}\text { Adaptation to growing conditions } \\
\text { in Europe and other temperate } \\
\text { regions }\end{array}$ & $1450-1900$ & $\begin{array}{c}\text { A subset of germplasm brought to } \\
\text { Europe serves as the foundation for } \\
\text { modern potato varieties. }\end{array}$ \\
\hline $\begin{array}{c}\text { Late blight pandemics } \\
\text { Seed tuber-borne viruses }\end{array}$ & $\begin{array}{c}\text { Mid-1800's; } 1900^{\prime} \mathrm{s} \\
\text { Trade barriers }\end{array}$ & $\begin{array}{c}\text { Late blight eliminates many potato } \\
\text { varieties. Resistance incorporated } \\
\text { from S. demissum. }\end{array}$ \\
\hline $\begin{array}{c}\text { Persistent } \\
\text { 19th and 20th century }\end{array}$ & $\begin{array}{c}\text { Clonally propagated potato lines "run } \\
\text { out" and are abandoned. }\end{array}$ \\
\hline $\begin{array}{c}\text { Germplasm exchange between } \\
\text { countries restricted by law and } \\
\text { phytosanitary barriers. }\end{array}$
\end{tabular}

\section{The Case for Continued Germplasm Enhancement}

The incorporation of novel traits from potato's wild relatives constitutes a relatively minor but important effort of breeding programs worldwide. The assumption has been that, as potato moved from its center of origin to Europe and across the globe, the genetic base of cultivated potato became increasingly narrow as a result of the sequential genetic bottlenecks described above. This assumption has been reinforced by efforts to identify sources of disease resistance and incorporate them into cultivated potato. Germplasm screens of wild species relatives for disease resistance have almost invariably found strong resistance, even when resistance is weak in cultivated potato [26]. Of course, we do not know if the resistance genes were present in ancestral potatoes and then subsequently lost, so we cannot conclude that bottlenecks are the cause of their absence. More fundamentally, we do not know how to determine when the genetic base of potato or any crop is too narrow for future breeding progress. We do know, however, that germplasm enhancement is needed whenever desirable traits or alleles are not present in accessible, cultivated material.

There are several classes of potato traits that are most likely to benefit from continued germplasm enhancement. These include those that confer resistance to existing and emerging pests and pathogens, contribute to improved processing quality, and promote resilience in the face of abiotic stress, including stresses linked to climate change and production under sub-optimal conditions. Consumer-oriented traits, such as color, flavor, and nutrition, can also benefit from germplasm enhancement efforts.

\subsection{Disease Resistance}

Our reliance on wild germplasm as a source of disease resistance will continue in perpetuity. Pathogens and pests spread with alarming regularity from one place on the globe to another and are under intense selection pressure to overcome plant resistance or develop resistance to pesticides. In native regions, the evolution of virulence genes in pathogen populations leads to selection pressure on host wild potato populations which then acquire and maintain corresponding resistance genes. Increased plant resistance results in reciprocal selection pressure on pathogen populations to overcome host resistance. This unending coevolution of host and pathogen populations ensures not only a perpetual source of new pathogen genotypes, but also a continuous supply of resistance genes for introduction into new cultivars. Although the generation of resistance to a novel pathotype could occur directly in cultivated potato, the continuous exposure of wild potato relatives to new pathogen genotypes means that there is a far greater likelihood of resistance developing there first. 
A comprehensive review of major crops found that the use of wild relatives by breeders as a source of disease resistance has had the greatest impact in potato, tomato, and wheat [27]. The authors suggested that, in these crops, germplasm resources are accessible and have received considerable attention from breeders. A recent genomics study revealed a high level of genetic diversity for disease resistance traits in wild potato species [28]. Thus, the case for continued use of germplasm enhancement to improve disease resistance seems strong. However, the authors point out that introgressions from only a small proportion of wild potato relatives (12 of the 107 wild species) are found in potato cultivars. This is despite considerable research on, and progress toward, overcoming hybridization barriers [29-31], and a long history of the use of wild potatoes in breeding programs, mostly for disease-resistance genes [32-34]. "There is a very great difference between the large number of wild species evaluated that show promise and the actual number used in breeding" [35]. In fact, only a small proportion of wild potato germplasm has even been evaluated for its potential to contribute to improved cultivars [36]. This is ironic, since potato, as an intensely-managed crop that has undergone significant bottlenecks, is likely to benefit from the introgression of wild germplasm more than most other crops [34].

The discrepancy between readily identified sources of disease resistance and infrequent incorporation into successful cultivars highlights the challenges associated with using traditional potato breeding approaches to introduce disease resistance. Interspecies hybrids created by crossing a wild relative to cultivated potato are genetically $50 \%$ wild. In traditional breeding programs, detrimental alleles from the wild species donor are eliminated through random assortment followed by phenotypic selection. This process requires years, and in some cases, decades, because progeny must contain the new trait of interest while maintaining other quality and production traits if they are to be used as parents for cultivar development. The time needed to eliminate unwanted wild germplasm traits may be long enough to allow pathogen populations to change and overcome resistance. For example, in the Columbia Basin of Washington and Oregon, late blight (Phytophthora infestans) was almost exclusively caused by the US-1 strain in 1992. By 1995, however, the US-8 strain accounted for $97 \%$ of late blight samples [37]. In 2009, the US observed a dramatic change in the occurrence of certain P. infestans lineages, with US-23 and US-24 strains essentially replacing the US-8 strain [38]. Potato cultivars Defender [39] and Jacqueline Lee [40], which were only bred for resistance to the US-8 strain of late blight, express weak resistance to the US-23 and US-24 strains [41], rendering them less desirable for commercial production.

In order to combat changes in pathogen genotypes more quickly, methods to quickly characterize emerging strains and implement strategies for rapid deployment of resistance are needed. Genomics tools will be a component of those methods. For example, a disease resistance trait may be localized to a discrete genetic region. This allows selection based on molecular markers rather than phenotype in segregating populations. Molecular markers for a number of disease resistance genes have been identified and are routinely used in potato breeding programs [42]. Most of these resistance genes have been identified and introgressed through germplasm enhancement efforts. The stacking of genes that confer resistance to multiple strains, as discussed later, would theoretically make it more difficult for pathogen populations to overcome resistance, as the pathogen would need to accumulate mutations at multiple virulence loci. Genomics tools also allow for targeted selection of cultivated haplotypes that are not linked to resistance loci, allowing for more rapid elimination of all other components of the wild species genome. These approaches, though possible with tetraploid potatoes, are much more efficient with diploids. Ongoing research suggests that diploid potatoes and genomics tools are likely to have synergistic effects on potato breeding [43-45].

\subsection{Processing Quality Traits}

Potato is the third most important food crop worldwide, and processed potatoes provide high value to growers. Wild species offer a source of natural genetic variation for improvements in processing potato products [46-49]. Germplasm enhancement has been used to improve potato tuber processing quality 
metrics, including dry matter content and resistance to cold-induced sweetening [48,50-52]. Germplasm enhancement also has the potential to contribute to improved processing quality by contributing to dry texture, uniformity in dry matter content, bruise resistance, and ideal starch composition. Unlike disease resistance traits, there is no a priori expectation that tuber quality traits will be simply inherited. Complex traits, such as dry matter uniformity throughout the tuber, are likely to be quantitative, and as such are influenced by multiple genetic loci and environmental interactions. Efficient introgression of multi-locus traits requires facile ways to monitor introduced genetic sequences. New genomics tools, such as genomic selection, will become required adducts to germplasm enhancement. In proof of concept research, genotyping-by-sequencing and genomic prediction were used to improve tuber quality traits in a tetraploid potato-breeding program [53]. Genomic models with moderate predictive value were developed for starch content and chip quality [54]. It should be noted that the high allelic diversity in tetraploid breeding clones necessitates the construction of large training populations in order to account for a wide range of phenotypic variability.

\subsection{Resilience to Abiotic Stress}

Potato breeders must develop cultivars that maintain yield and tuber quality when challenged with a range of abiotic stresses. These may include elevated day- or night-time temperatures that inhibit photosynthesis and decrease tuber starch accumulation, late spring frosts that damage young tissues, and heavy rains that cause transient water logging. Additional mild environmental stress may be imposed by growers who reduce nutrient or water applications to fields in an effort to meet environmental sustainability goals. Unlike cultivated potato, which is native to the high Andes and is adapted to cool climate growing conditions, wild relatives of potato are adapted to an extremely wide range of environmental conditions [55-57]. Major contributions of wild species genes in early domesticates appear to be related to biotic and abiotic stress tolerance. This was likely critical for the migration of potato from the high Andes to the coast of Chile [10]. Similarly, in tomato, abundant transcriptional variation was found among wild species for genes associated with biotic and abiotic stress tolerance [58]. Much of this stress tolerance appears to have been lost since early domestication events and will need to be retrieved again from wild relatives via germplasm enhancement. The timeliness of the alignment of emerging genomics technologies with the development of improved germplasm resources (e.g., diploid inbreds) is fortuitous, considering the projected negative impact of climate change on potato production [59]. According to Slater et al. [60], the use of "genomic selection, in conjunction with the diverse nature of the entire potato gene pool, will enable germplasm to be rapidly developed for emerging issues, such as the threat of global climate change and associated changes in abiotic and biotic stresses."

Unlike disease resistance, which is often species-specific, common abiotic stress resistance mechanisms are shared among species. Because of this, germplasm enhancement for abiotic stress resistance will look both to the diversity found in wild potato relatives and to the resistance mechanisms identified in more distantly-related plants. Molecular biology approaches could be used to introduce alleles from those species into potato. As an example, resistance to drought and salinity stress in many species is promoted by the accumulation of the osmolyte glycine betaine [61]. Potato does not accumulate glycine betaine naturally, but transformation of potato with the spinach $B A D H$ gene, which produces an enzyme in glycine betaine synthesis, increased the drought and salinity tolerance of the transformed potato lines [62]. Alternatively, wild and cultivated potato could be screened for allelic sequences containing DNA motifs identified as conferring a favorable phenotype in other species. Individuals with similar sequences would be candidates for use in germplasm enhancement. For example, a search in potato germplasm for transcription factors that contribute to salt and drought stress tolerance in tomato, such as SlbZIP1 [63], may identify targets for introgression into potato breeding programs. Alternatively, the SlbZIP1 ortholog in potato could be edited to match that in tomato. Assuming other components needed for its expression and regulation are present, the edited potato gene would provide stress tolerance. 


\subsection{Consumer Traits}

The demand for improved consumer-oriented traits (e.g., tuber color and flavor) and enhanced nutritional quality (e.g., mineral content, protein content, vitamin C, fiber) continues to increase, and wild species and landraces provide a relatively untapped supply of these characteristics $[64,65]$. While some may be simply inherited or determined by a small number of genes [66], in most cases, these genes are not yet known and gene identification will require extensive phenotyping. Improvements in complex traits, such as after-cooking texture, will likely require manipulating several genes or the reconstitution of entire metabolic pathways. In the past, it would have been a prohibitive undertaking to incorporate multi-genic traits into new cultivars, limiting the usefulness of the donor wild species. However, advances in genetic and genomics tools now allow us to identify the numerous sequences involved in multi-genic traits and simultaneously move them into new cultivars.

\section{Germplasm Resources}

Genetic diversity is the raw material for germplasm enhancement. Although diversity per se has no value in breeding, allelic variants alone or in combination may confer desirable traits. The challenge is to find beneficial alleles and assemble them into functional units in elite cultivated potato. Genomics tools allow desirable allelic variants to be identified and tracked more easily than in the past. Sources of genetic material that can be used for germplasm enhancement are summarized in Table 2.

Table 2. Potato germplasm resources available for enhancement efforts.

\begin{tabular}{|c|c|c|c|}
\hline Germplasm & Use & Limitations & Genomics Tools \\
\hline $\begin{array}{c}\text { Potato cultivars } \\
\text { (Solanum tuberosum) }\end{array}$ & $\begin{array}{l}\text { Enrichment of rare and } \\
\text { recessive alleles }\end{array}$ & $\begin{array}{l}\text { Rare alleles are difficult } \\
\text { to identify; recessive } \\
\text { phenotype not apparent } \\
\text { until homozygous }\end{array}$ & $\begin{array}{l}\text { Sequencing and genetic } \\
\text { markers used to } \\
\text { efficiently find and track } \\
\text { incorporation of rare and } \\
\text { recessive alleles }\end{array}$ \\
\hline $\begin{array}{c}\text { Landraces (Solanum } \\
\text { tuberosum) }\end{array}$ & $\begin{array}{l}\text { Restoration of alleles lost } \\
\text { to bottlenecks }\end{array}$ & $\begin{array}{c}\text { Landraces lack modern } \\
\text { domestication traits such } \\
\text { as photoperiod } \\
\text { adaptation, long tuber } \\
\text { dormancy and smooth } \\
\text { tuber shape }\end{array}$ & \multirow[t]{2}{*}{$\begin{array}{l}\text { Marker-assisted selection } \\
\text { for major gene traits; } \\
\text { dense marker arrays to } \\
\text { reduce linkage drag }\end{array}$} \\
\hline $\begin{array}{c}\text { Tuber-bearing wild } \\
\text { potato relatives (Solanum } \\
\text { section Petota) }\end{array}$ & $\begin{array}{l}\text { Novel alleles lost to } \\
\text { bottlenecks or never } \\
\text { introgressed into } \\
\text { cultivated germplasm }\end{array}$ & $\begin{array}{l}\text { Numerous crosses to } \\
\text { cultivated potato are } \\
\text { required to restore } \\
\text { commercial quality }\end{array}$ & \\
\hline Genus Solanum & $\begin{array}{l}\text { Allelic variants outside } \\
\text { the potato gene pool }\end{array}$ & $\begin{array}{l}\text { Phenotype in } \\
\text { commercial potato } \\
\text { cannot be predicted } \\
\text { accurately in silico }\end{array}$ & $\begin{array}{l}\text { Sequence data identify } \\
\text { allelic variants across a } \\
\text { wide range of related } \\
\text { species; gene editing to } \\
\text { create new phenotypes }\end{array}$ \\
\hline
\end{tabular}

\subsection{Solanum Tuberosum}

Plant breeding convention suggests that cultivated germplasm is preferable to wild for cultivar improvement. However, landraces have not been used in potato breeding as much as might be expected. Cultivated potatoes from the equatorial Andes are not adapted to temperate regions. Large efforts in both North America and Europe to select for photoperiod adaptation in tetraploid Andean germplasm were successful in creating so-called Neo-tuberosum germplasm [67-72]. Similar efforts have been carried out on diploid cultivated germplasm [73,74]. However, this germplasm continues to pose challenges to breeders, as persistent problems include long stolons, small tubers, late maturity, male sterility, short tuber dormancy, and prolonged tuber initiation, leading to variability in tuber size 
at harvest $[75,76]$. Furthermore, in the past, the use of landraces was discouraged because much of the material housed in potato germplasm collections was infected with viruses [77].

In the genomics era, the identification of genetic regions associated with the negative traits listed above is an achievable goal. Selection against those regions can be carried out using backcrosses following the initial hybridization event. Conversely, positive selection will be possible for complex traits unique to landraces, such as good flavor and nutritional quality [78-80]. It is also easy to imagine how genomics tools, particularly high-throughput resequencing, could be used to identify rare alleles and recessive alleles in cultivated potato. Until the genomics era, these genetic resources were virtually inaccessible to potato breeders. Recessive alleles are rarely homozygous in polyploid crops, and thus their phenotype and potential use in breeding has gone unnoticed [81,82]. Likewise, rare alleles are only likely to be uncovered if they are present in germplasm currently being used for breeding. Older varieties no longer being used as parents in breeding programs, sterile cultivars, and landraces not adapted to temperate regions are potential sources of rare alleles, but in the absence of a targeted genetic search for sequence variants, those alleles remain outside of the genetic pool available for germplasm improvement. Genotyping by sequencing combined with haplotype characterization was shown to be an efficient method to characterize allelic variants at the E3 maturity locus of soybean [83], and this approach should be amenable to potato as well.

\subsection{Solanum Section Petota}

Breeders have access to extensive wild potato germplasm resources in genebanks, and wild relatives have been a major focus of germplasm enhancement efforts. Diverse populations of wild potatoes are found over a distance of $10,000 \mathrm{~km}$, from the southwest United States to southern regions of Chile and Argentina. Their habitats range from coastal regions to high elevations (Figure 1) and from cloud forests to deserts [18,55]. Relatives of the cultivated potato, Solanum section Petota, include 107 wild and cultivated species [5]. Most wild potatoes are diploid, although there are also tetraploid and hexaploid species.

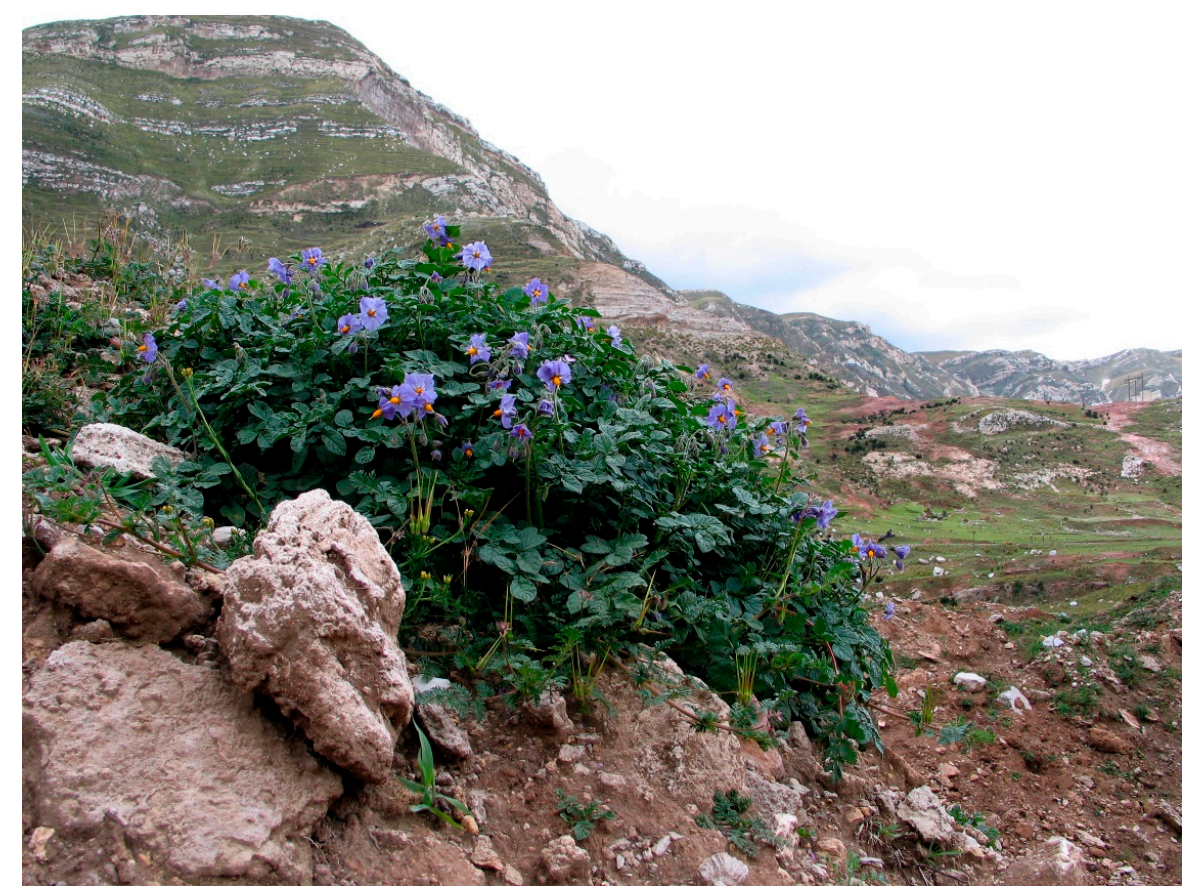

Figure 1. Wild potatoes, such as S. candolleanum in the high Andes, grow in a wide range of environments. They are especially valuable as sources of resistance to biotic and abiotic stresses. 
The majority of wild potato species are self-incompatible, but sexually compatible with cultivated germplasm $[5,29,34,84,85]$. Wild potatoes reproduce both sexually and asexually, but the predominant mode of reproduction is not known [86]. It likely varies among populations, depending on environment and the need for genetic flexibility. Solanum flowers are buzz-pollinated by bees, which collect pollen as a source of nutrition for larvae [18]. Wild potatoes exhibit both external (geography, ecology) and internal (pre-zygotic and post-zygotic) hybridization barriers, but these barriers are incomplete [86]. Consequently, a wild population may consist of a mixture of plants carrying only the parental species genome and those in various stages of hybridization and introgression. Consequently, characterization of wild potato germplasm is "complicated by introgression, interspecific hybridization, auto- and allopolyploidy, sexual incompatibility, a mixture of sexual and asexual reproduction, possible recent species divergence, phenotypic plasticity..." [86]. An incomplete picture of the reproductive biology of wild potato populations hinders our understanding of sources of genetic variability within and among these populations and, therefore, our understanding of the genetic makeup of genebank accessions used for germplasm enhancement.

Traditional germplasm enhancement efforts have focused on sexual hybridization to transfer traits of interest from wild to cultivated potato [34,84,87-92]. In some cases, alternative approaches such as protoplast fusion and embryo rescue have been used (reviewed in Ref. [29]). The genomics era will introduce the power to identify the specific allelic variants that influence traits. When valuable alleles are identified and introgressed through hybridization, dense marker data can be used subsequently to efficiently retain the desirable allele while removing the remaining donor genome. This process will be more effective in diploid inbred germplasm than in heterozygous tetraploids.

\subsection{Genus Solanum}

Cultivated potatoes (Solanum tuberosum) and tomatoes (Solanum lycopersicum) are sister taxa that diverged only 8 million years ago [19]. As such, genetic similarities are abound. The potato genome was published in 2011 [93], followed a year later by the tomato genome [94]. Both have a basic set of 12 chromosomes in which the gene order is retained except for nine inversions. A comparison of tomato and potato euchromatic regions found only $8.7 \%$ divergent nucleotides. Despite the potential benefits of sharing genetic resources, potato and tomato breeders have largely worked independently of each other. As we move into the genomics era, it is time to begin to consider potato and tomato as collections of overlapping genes and genetic systems.

Domestication traits for tomato focus on fruit size and shape [94], including the OVATE gene for shape [95]. The application of this knowledge about OVATE for potato breeding may not be apparent, but it is a member of the OVATE Family Protein class of genes, which also regulate potato tuber shape [96]. In addition to common genetic systems for tuber and fruit shape, an overlap in tuber quality genes exists. In potato, tubers used for processing must possess low levels of reducing sugars. In tomato, sugar production is an important trait for breeders. The potato invertase gene invGE is orthologous to the tomato LIN5 gene that influences Brix score [97]. Comparative genomics of the Solanaceae with respect to disease resistance suggests the conservation of resistance-related genes at orthologous locations throughout the genomes of potato, tomato, and pepper although their specificities may not be conserved [98-100]. Given the structural co-linearity between tomato and potato, these species can be used for comparative genomics to isolate genes of interest, which has been done in the case of $R 3 a$ for late blight resistance [101]. In some cases, evidence has demonstrated cross-functionality of $R$ genes within the Solanaceae, suggesting a conservation of pathways that lead to the activation of resistance to late blight [102,103], Cladosporium fulvum [104], and viruses [105]. As tomato genomics research expands, breeders would do well to leverage the knowledge gained for potato improvement. 


\section{Germplasm Collections in the Genomics Era}

As we move into the genomics era, it is important to reexamine the activities of genebanks. Certainly, the five cornerstone goals-acquisition, classification, preservation, evaluation, and distribution-must be preserved. However, placing a greater emphasis on genotypic rather than phenotypic data could reap significant rewards. There is a growing emphasis on considering genebank holdings as a collection of alleles rather than plants [106,107]. The focus on plant genotypes rather than phenotypes may allow breeders to discover valuable new and perhaps unexpected genetic diversity.

Assembled genome sequences for two wild potato species have been published to date $[108,109]$. Additional sequencing of wild species and resequencing of genebank collections will provide insights into genetic similarities and differences among species and accessions. Since most wild potatoes are diploid, the complexities of polyploid genomic analyses can be avoided for the most part. A large sequencing effort on 84 tomato genomes has recently revealed extensive species- and accession-specific polymorphisms [110]. Similarly, genomic analysis of 201 wild and cultivated potato accessions revealed high levels of diversity, especially in wild populations, and over 600 genes associated with domestication traits [28]. As genome annotation information grows, scientists will be able to identify SNPs in or near genes of interest and predict whether they are likely to result in a functionally different protein product [106].

Predicting sources of genetic variation in genebank collections is complicated since the greatest source of variation can be either within or among accessions, depending on the germplasm sampled [111-113]. This is not surprising, considering that every wild population has a different history. In general, though, genetic variation is far greater in allogamous than autogamous accessions, both in potato $[113,114]$ and tomato [115]. An AFLP marker study of 17 wild potato accessions found that any randomly selected plant contains $91 \%$ of the markers in the parent accession in self-compatible species, but only $77 \%$ in self-incompatible species [113]. In addition, $57 \%$ and $67 \%$ of markers in each taxon were contained in the sampled accessions of self-compatible and self-incompatible species, respectively. Based on the Infinium 8303 SNP array, which was generated from transcribed sequences in cultivated potato, genetic distances among wild plants within accessions of self-incompatible species were smaller than those among accessions of the same species [116]. Consequently, efforts to enhance genetic diversity in breeding programs should focus on many plants across accessions rather within accessions.

\section{Identifying Valuable Germplasm}

Conventional potato germplasm enhancement efforts begin with phenotypic screens of wild potato accessions. Because repositories such as the U.S. Potato Genebank carry thousands of accessions, it can be difficult to identify a subset for phenotyping. Each wild species is typically distributed across a range of climatic conditions [55] and interspecific hybridization is common $[117,118]$. Consequently, each accession of a species has a unique evolutionary history and may be quite different from the others. This presents challenges when searching for sources of traits. Statements such as "In South America, it [immunity to potato virus Y] is chiefly to be seen in S. chacoense ... " [56] do not provide the breeder with much guidance. The U.S. Potato Genebank, for example, maintains 167 accessions of $S$. chacoense. To address this challenge, a series of studies was carried out to determine whether taxonomic or biogeographic data could be used to predict the distribution of disease and pest resistance phenotypes in wild relatives of potato [119-125]. These studies were designed to test prediction at the section and species level without prior knowledge of phenotypes. In general, predictivity was poor due to the complex evolutionary history of wild potato populations in combination with the inability to infer genotype based on the resistance phenotype. In contrast to disease and pest resistance traits, inter-accession variability can be low for some traits that are consistently experienced by a species, such as stress tolerance, as discussed above. For example, S. acaule typically grows at elevations above $4000 \mathrm{~m}$ [126], so accessions are uniformly frost tolerant [127]. For such traits, a Focused Identification of Germplasm Strategy may be useful to identify valuable wild germplasm [128]. 
For many traits, then, breeders must search through a wide array of phenotypically and genotypically diverse germplasm. The phenotyping challenge can be demonstrated by examining evaluation data in the U.S. Potato Genebank. For example, several evaluations by highly-qualified specialists have been carried out for resistance to Verticillium wilt, caused by a soil-borne fungus. Table 3 illustrates discrepancies between studies. Phenotypic evaluations of resistance varied in several ways, including whether they were performed in the field or greenhouse, whether soil was inoculated or not, and how plants were classified as resistant. Plant phenotype results from a complex interaction among genes and between those genes and the environment. Consequently, phenotypic variation does not necessarily mirror genetic variation $[107,129]$.

Table 3. Classification of resistance to Verticillium wilt caused by V. dahliae, showing variability in resistance classification among studies. Data are from the U.S. Potato Genebank.

\begin{tabular}{cccccc}
\hline Accession & Classification & Study & Location & Inoculated & Scoring Method \\
\hline PI 225697 & Resistant & Ander84 & Field & yes & $\begin{array}{c}\text { Number of propagules in } \\
\text { stems }\end{array}$ \\
\cline { 2 - 6 } PI 230463 & Susceptible & Corsi84 & Field & no & $\begin{array}{c}\text { Incidence and severity of } \\
\text { symptoms }\end{array}$ \\
\cline { 2 - 6 } & Susceptible & Corsi84 & Field & no & $\begin{array}{c}\text { Incidence and severity of } \\
\text { symptoms }\end{array}$ \\
\hline PI 230473 & Resistant & Corsi84 & Field & no & $\begin{array}{c}\text { Incidence and severity of } \\
\text { symptoms }\end{array}$ \\
\cline { 2 - 6 } & Susceptible & Rowe85 & Greenhouse & yes & Symptoms \\
\hline PI 230503 & Susceptible & Ander83 & Field & yes & $\begin{array}{c}\text { Number of propagules in } \\
\text { stems }\end{array}$ \\
\cline { 2 - 6 } & Very resistant & Corsi83 & Field & no & $\begin{array}{c}\text { Symptoms and propagules } \\
\text { in stems }\end{array}$ \\
\hline
\end{tabular}

Genomics resources and molecular biology tools now allow us to relatively rapidly identify germplasm to facilitate the mapping of novel $R$ genes from wild potato species for marker development or cloning. At the core of these technologies is a reduction in the complexity of the potato genome in order to simplify sequencing approaches and identify genetic polymorphisms that correlate with resistance phenotypes. Diversity Array Technology was effective in identifying genomic sequence variability in S. bulbocastanum and S. commersonii [130]. Resistance $(R)$ gene enrichment sequencing (RenSeq) relies on the purification of predicted $R$ genes from wild species for high-throughput sequencing [131] or to identify and track previously unknown $R$ genes in cultivated germplasm [132]. Similarly, GenSeq uses single/low copy number genes to identify markers associated with resistance, when a known $R$ gene is not present [133].

Genomics tools can also be applied to facilitate selection for disease resistance. Dominant resistance in plant hosts is typically dependent on the plant's ability to recognize the presence of specific pathogen virulence proteins, termed effectors. Effector complements of pathogens can be complex. The potato late blight pathogen, P. infestans, is predicted to contain several hundred effectors [134-136]. Each of these effectors can be used to identify Solanum germplasm that contains a corresponding resistance protein through transient expression [137]. This has allowed for relatively rapid identification of novel sources of disease resistance within the Solanum germplasm pool without the need for pathogen inoculations, which typically require tightly-regulated growing conditions and adequate space for screening. Although effector prediction in many other plant pathogens is currently behind that of $P$. infestans, similar genomics approaches could be used to identify effector sets in order to facilitate phenotypic selection for disease resistance. 
Because most wild potatoes are allogamous, plants within accessions are typically heterozygous and heterogeneous. Consequently, if a trait is reported in an accession, additional fine screening is needed to identify individuals in that accession that express the phenotype [138-141]. After a plant of interest is identified by fine screening, it is typically crossed with cultivated germplasm [138-141]. These clones are rarely shared among breeding programs or maintained for the long term. Follow-up studies cannot go back to the original source of the trait, so opportunities to link genotype to phenotype are lost. As we move into the genomics era, it will be of value to clonally maintain selected wild plants along with their genotype and phenotype data in genebanks. Genebank users can then request these clones for additional phenotyping studies. The research community would then be able to build on the dataset, improving sequence data and adding phenotype data across time. By accumulating a broad array of phenotype data on the same collection of plants, it may be possible to identify interactions between traits that were not apparent before. Over time, as genomic prediction models evolve, it may be possible to predict which species and accessions to add to a clonal wild species collection to best contribute useful new genetic variation.

\section{Incorporating Traits into Cultivated Potato}

Donor individuals with desirable traits or allelic variants can be identified by evaluating phenotype or genotype as appropriate. Introgression of advantageous genetic sequences into cultivated potato can be done through sexual hybridization or using molecular approaches. Genomics tools can increase the efficiency of both approaches.

\subsection{Sexual Hybridization}

Conventional potato breeding is based on making crosses between heterozygous tetraploid parents that complement each other for traits of interest [142-145]. Phenotypic selection is then carried out in the resulting progeny, with $90 \%$ or more of the new genetic combinations discarded after a cursory evaluation. Recombination in heterozygous tetraploid parents breaks up desirable dominance and epistatic interactions, leading to inferior progeny [146]. Superior new genetic combinations are rare. In addition, important market traits, such as tuber shape and skin color, are not fixed in breeding programs. According to Bradshaw [144], “ ... in a single cross, the frequency of clones combining all of the desirable characteristics of the two parents is extremely low. Without efficient recurrent selection, breeders will simply be shuffling genes with each generation of crosses without making real progress ..." These problems have been recognized by potato breeders for nearly a century [147-149].

The most common method for introgressing wild potato alleles is crossing cultivated clones to wild species to create interspecies hybrids. Selection pressure is relaxed in hybrid populations and their offspring, since linkage drag is expected. However, after the initial selection is made in a segregating family, all subsequent selection events are based on clonal material. That is, no recombination occurs in later years of evaluation. It is not surprising then, that although selections carrying wild species introgressions may be retained early in a breeding program, they are typically discarded in later clonal generations because of disadvantageous traits acquired from the wild parent. Additional crosses between the interspecies hybrid and cultivated potato may improve the overall quality of the progeny over many generations by removing unwanted alleles, but this process is very slow in potato, where approximately 50 quality traits are used as criteria for commercial success. Recombination is needed to separate desirable genetic loci from undesirable ones. However, there is typically only one crossover per chromosome pair in potato per generation [150], so several generations of recombination are needed to minimize the size of an exotic introgression. Genomics tools can make this process more efficient by assessing the genomic locations of DNA contributed by the wild and cultivated parents. Progeny used for additional hybridizations with cultivated potato could be those with the highest probability of removing wild species DNA given the position and size of previous recombination events and the expected frequency of future recombination at various locations along each chromosome. Current efforts to convert potato into a diploid inbred-hybrid crop will allow us to harness the power of genetics 
and genomics to select for and fix desirable genetic variants while eliminating deleterious alleles [43-45]. For example, unwanted genetic material could be removed strategically from interspecies hybrids by using backcrosses to the inbred, cultivated parent in combination with marker data.

\subsection{Molecular Approaches}

Germplasm enhancement no longer relies solely on making crosses to transfer genetic material from individuals of donor species to cultivated potato. Molecular approaches offer an alternative approach that reduces the amount of unwanted genetic material incorporated along with a desirable trait. For example, allelic variants identified elsewhere can be constructed in vivo using gene editing or mutagenesis rather than being introduced by crossing. Entire genes, or groups of genes, can be introduced using plant transformation approaches. As mentioned previously, when resistance gene-identifying tools are combined with genetic engineering or gene editing technologies, the time required to identify and deploy an $R$ gene or genes is dramatically reduced. A biotechnology-assisted approach has been used to incorporate PVY resistance found in pepper into cultivated potato by transformation with the pepper resistance allele por1, which encodes a variant of the transcriptional initiation factor eIF4E [105]. Similarly, a gene functionally analogous to por1, but naturally occurring in S. chacoense, was identified and introduced into cultivated potato using stable transformation [151]. Using a slightly different approach, the endogenous potato eIF4E gene was mutated in vitro to mirror por1 functionality and re-introduced into potato, where it conferred PVY resistance [105,152]. Multiple late blight resistance genes from wild species relatives have been introduced into cultivated potato using stable transformation, and complete resistance to the disease was accomplished without impacting marketable or total yield [153]. Gene editing using CRISPR-cas9 has been used recently to improve resistance to cold-induced sweetening [154] and to render non-functional the S-RNase in potato and confer self-compatibility to previously incompatible plants [155]. In all of these cases, little or no unwanted and potentially detrimental genomic sequence was introduced with the sequence of interest. Gene-stacking technologies, such as GAANTRY [156], would allow for the simultaneous introduction of multiple $R$ genes, decreasing the likelihood that the targeted pathogen(s) will rapidly overcome resistance. Genomics approaches are needed when using molecular methods for incorporating molecular traits. Markers and DNA or RNA sequencing are needed to identify individuals with the correct sequence or transgene, and detailed phenotyping will be needed to ensure that the molecular methods have not introduced mutated sequences or an inappropriate number of copies of the correct sequence. Phenotypic assays are still required to demonstrate that the introduced genes confer the desired trait. For example, genetically-modified lines of potato were created using RNA-interference to suppress the expression of the vacuolar invertase gene. Lines containing the silencing construct varied widely in their ability to suppress invertase gene expression and confer resistance to cold-induced sweetening or sugar end defects $[49,157]$.

\section{Identifying Superior Genotypes}

Individuals that have acquired traits through germplasm enhancement must be identified. Phenotypic evaluation will continue to be used for easily screened traits, especially dominant traits. For multi-locus traits and for traits conferred by recessive alleles, whole genome selection will be required to identify valuable individuals and utilize them in further pre-breeding efforts. The development of genomic prediction models will allow potato breeders to use genomic selection to supplement or, in some cases, replace phenotypic selection. This research area is in its infancy in potato, but early reports suggest to us that genomic selection will be a valuable tool for future potato breeding and germplasm enhancement efforts $[53,54,60,155,158]$.

\section{Conclusions}

Potato breeders will continue to rely on germplasm enhancement for variety improvement. In the genomics era, germplasm enhancement will increasingly be focused on identifying and introgressing 
alleles rather than phenotypic traits. Alleles will come from a broad pool of genetic resources that includes wild species relatives of potato, landraces, cultivated potato itself, and distantly-related species. Genomics tools will greatly increase the efficiency of introgressing multi-genic traits and will make it possible to identify rare alleles and utilize recessive alleles. Introgression may occur through sexual hybridization, or molecular manipulations, but evaluation of progeny will increasingly involve assessing allelic composition and distribution of parental genomes.

\section{Dedication}

We dedicate this paper to Dr. David Spooner, in recognition of 33 years of outstanding contributions to the field of potato taxonomy with a special emphasis on the collection and characterization of wild potato relatives.

Author Contributions: All authors contributed equally to writing the manuscript.

Funding: Authors are funded by USDA-ARS Project Number 5090-21220-005-00D.

Acknowledgments: In this section you can acknowledge any support given which is not covered by the author contribution or funding sections. This may include administrative and technical support, or donations in kind (e.g., materials used for experiments).

Conflicts of Interest: The authors declare no conflict of interest.

\section{References}

1. Spooner, D.M.; Ruess, H.; Arbizu, C.I.; Rodríguez, F.; Solís-Lemus, C. Greatly reduced phylogenetic structure in the cultivated potato clade (Solanum section Petota pro parte). Am. J. Bot. 2018, 105, 60-70. [CrossRef] [PubMed]

2. Spooner, D.M.; McLean, K.; Ramsay, G.; Waugh, R.; Bryan, G.J. A single domestication for potato based on multilocus amplified fragment length polymorphism genotyping. Proc. Natl. Acad. Sci. USA 2005, 102, 14694-14699. [CrossRef] [PubMed]

3. Iwanaga, M.; Peloquin, S.J. Origin and evolution of cultivated tetraploid potatoes via $2 n$ gametes. Theor. Appl. Genet. 1982, 61, 161-169. [CrossRef] [PubMed]

4. Camadro, E.; Peloquin, S.J. Polyploid evolution of wild potatoes via genetically determined $2 n$ gametes. Am. Potato J. 1980, 57, 473.

5. Spooner, D.M.; Ghislain, M.; Simon, R.; Jansky, S.H.; Gavrilenko, T. Systematics, diversity, genetics, and evolution of wild and cultivated potatoes. Bot. Rev. 2014, 80, 283-383. [CrossRef]

6. Rodríguez, F.; Ghislain, M.; Clausen, A.M.; Jansky, S.H.; Spooner, D.M. Hybrid origins of cultivated potatoes. Theor. Appl. Genet. 2010, 121, 1187-1198. [CrossRef] [PubMed]

7. Brush, S.B.; Carney, H.J.; Huaman, Z. Dynamics of Andean potato agriculture. Econ. Bot. 1981, 35, 70-88. [CrossRef]

8. Quiros, C.F.; Brush, S.B.; Douches, D.S.; Zimmerer, K.S.; Huestis, G. Biochemical and folk assessment of variability of Andean cultivated potatoes. Econ. Bot. 1990, 44, 254-266. [CrossRef]

9. Spooner, D.M.; Gavrilenko, T.; Jansky, S.H.; Ovchinnikova, A.; Krylova, E.; Knapp, S.; Simon, R. Ecogeography of ploidy variation in cultivated potato (Solanum sect. Petota). Am. J. Bot. 2012, 97, 2049-2060. [CrossRef]

10. Hardigan, M.A.; Laimbeer, F.P.E.; Newton, L.; Crisovan, E.; Hamilton, J.P.; Vaillancourt, B.; Wiegert-Rininger, K.; Wood, J.C.; Douches, D.S.; Farré, E.M.; et al. Genome diversity of tuber-bearing Solanum uncovers complex evolutionary history and targets of domestication in the cultivated potato. Proc. Natl. Acad. Sci. USA 2017, 114, E9999-E10008. [CrossRef]

11. Grun, P. The evolution of cultivated potatoes. Econ. Bot. 1990, 44, 39-55. [CrossRef]

12. Soyk, S.; Müller, N.A.; Park, S.J.; Schmalenbach, I.; Jiang, K.; Hayama, R.; Zhang, 1.; van Eck, J.; Jiménez-Gomez, J.M.; Lippman, Z.B. Variation in the flowering gene Self Pruning 5G promotes day-neutrality and early yield in tomato. Nat. Genet. 2017, 49, 162-168. [CrossRef] [PubMed]

13. Kittipadukal, P.; Bethke, P.C.; Jansky, S.H. The effect of photoperiod on tuberisation in cultivated $\mathrm{x}$ wild potato species hybrids. Potato Res. 2012, 55, 27-40. [CrossRef] 
14. O'Brien, P.; Allen, E.; Firman, D. A review of some studies into tuber initiation in potato (Solanum tuberosum) crops. J. Agric. Sci. 1998, 130, 251-270. [CrossRef]

15. Kloosterman, B.; Abelenda, J.A.; Gomez, M.D.M.C.; Oortwijn, M.; De Boer, J.M.; Kowitwanich, K.; Horvath, B.M.; Van Eck, H.J.; Smaczniak, C.; Prat, S.; et al. Naturally occurring allele diversity allows potato cultivation in northern latitudes. Nature 2013, 495, 246-250. [CrossRef] [PubMed]

16. Ríos, D.; Ghislain, M.; Rodriguez, F.; Spooner, D.M. What is the origin of the European potato? Evidence from Canary Island landraces. Crop Sci. 2007, 47, 1271-1280. [CrossRef]

17. Ames, M.; Spooner, D.M. DNA from herbarium specimens settles a controversy about origins of the European potato. Am. J. Bot. 2008, 95, 252-257. [CrossRef]

18. Peralta, I.; Spooner, D.; Knapp, S. Taxonomy of wild tomatoes and their relatives (Solanum sect. Lycopersicoides, sect. Juglandifolia, sect. Lycopersicon; Solanaceae. Syst. Bot. Monogr. 2008, 84, 186.

19. Knapp, S.; Peralta, I. The tomato (Solanum lycopersicum L.) and its botanical relatives. In The Tomato Genome; Causse, M., Giovannoni, J., Bouzayen, M., Zouine, M., Eds.; Springer: Berlin, Germany, 2016; pp. 7-21.

20. Gutaker, R.M.; Weiß, C.L.; Ellis, D.; Anglin, N.L.; Knapp, S.; Fernández-Alonso, J.L.; Prat, S.; Burbano, H.A. The origins and adaptation of European potatoes reconstructed from historical genomes. Nat. Ecol. Evol. 2019, 3, 1093-1101. [CrossRef]

21. Pavek, J.J.; Corsini, D.L. Utilization of potato genetic resources in variety development. Am. J. Potato Res. 2001, 78, 433-441. [CrossRef]

22. Glendinning, D.R. Potato introductions and breeding up to the early 20th century. New Phytol. 1983, 94, 479-505. [CrossRef]

23. Clark, C. Potato breeding investigations in 1938: Review of literature. Am. Potato J. 1938, 16, $212-220$. [CrossRef]

24. Stevenson, F.J.; Clark, C.F. Breeding and genetics in potato improvement. Yearb. Agric. USDA 1937, 405-444.

25. Bradshaw, J.E.; MacKay, G.R. Breeding strategies for clonally propagated crops. In Potato Genetics; Bradshaw, J.E., MacKay, G.R., Eds.; CAB International: Wallingford, UK, 1994; pp. 467-497.

26. Jansky, S.H. Breeding for disease resistance in potato. Plant Breed. Rev. 2000, 19, 69-155.

27. Lenne, J.M.; Wood, D. Plant diseases and the use of wild germplasm. Annu. Rev. Phytopathol. 1991, $29,35-63$. [CrossRef]

28. Li, Y.; Colleoni, C.; Zhang, J.; Liang, Q.; Hu, Y.; Ruess, H.; Simon, R.; Liu, Y.; Liu, H.; Yu, G.; et al. Genomic analyses yield markers for identifying agronomically important genes in potato. Mol. Plant 2018, 11, $473-484$. [CrossRef]

29. Jansky, S. Overcoming hybridization barriers in potato. Plant Breed. 2006, 125, 1-12. [CrossRef]

30. Camadro, E.L.; Carputo, D.; Peloquin, S.J. Substitutes for genome differentiation in tuber-bearing Solanum: Interspecific pollen-pistil incompatibility, nuclear-cytoplasmic male sterility, and endosperm. Theor. Appl. Genet. 2004, 109, 1369-1376. [CrossRef] [PubMed]

31. Hanneman, R.E., Jr. The potato germplasm resource. Am. Potato J. 1989, 66, 655-667. [CrossRef]

32. Vincent, H.; Wiersema, J.; Kell, S.; Fielder, H.; Dobbie, S.; Castañeda-Álvarez, N.P.; Guarino, L.; Eastwood, R.; León, B.; Maxted, N. A prioritized crop wild relative inventory to help underpin global food security. Biol. Conserv. 2013, 167, 265-275. [CrossRef]

33. Jansky, S.; Spooner, D. Evolution of potato breeding. Plant Breed. Rev. 2018, 41, 169-214.

34. Bethke, P.; Halterman, D.; Jansky, S. Are we getting better at using wild potato species in light of new tools? Crop Sci. 2017, 57, 1-18. [CrossRef]

35. Hawkes, J.G. The Potato: Evolution, Biodiversity, and Genetic Resources; Smithsonian Institution Press: Washington, DC, USA, 1990; p. 259.

36. Castaeda-Alvarez, N.P.; de Haan, S.; Juarez, H.; Khoury, C.K.; Achicanoy, H.A.; Sosa, C.C.; Bernau, V.; Salas, A.; Heider, B.; Simon, R.; et al. Ex situ conservation priorities for the wild relatives of potato (Solanum L. section Petota). PLoS ONE 2015, 10, e0129873. [CrossRef]

37. Johnson, D.A.; Cummings, T.F.; Rower, R.C.; Miller, J.S.; Thornton, R.E.; Pelter, G.Q.; Sorensen, E.J. Potato late blight in the Columbia Basin: An economic analysis of the 1995 epidemic. Plant Dis. 2007, 81, 103-106. [CrossRef] [PubMed] 
38. Fry, W.E.; Myer, K.; Roberts, P.; McGrath, M.T.; Everts, K.; Secor, G.; Seaman, A.; Gevens, A.J.; Seebold, K., Jr.; Zigger, T.A.; et al. The 2009 late blight pandemic in the Eastern United States-causes and results. Plant Dis. 2012, 97, 296-306. [CrossRef] [PubMed]

39. Novy, R.; Love, S.L.; Corsini, D.L.; Pavek, J.J.; Whitworth, J.L.; Mosley, A.R.; James, S.R.; Hane, D.C.; Shock, C.C.; Rykbost, K.A.; et al. Defender: A high-yielding, processing potato cultivar with foliar and tuber resistance to late blight. Am. J. Potato Res. 2006, 83, 9-19. [CrossRef]

40. Douches, D.; Jastrzebski, K.; Coombs, J.; Kirk, W.W.; Felcher, K.K.; Hammerschmidt, R.; Chase, R.W. Jacqueline Lee: A late-blight-resistant tablestock variety. Am. J. Potato Res. 2001, 78, 413-419. [CrossRef]

41. Sanchez-Perez, A.; Halterman, D.; Jordan, S.; Chen, Y.; Gevens, A.J. RB and Ph resistance genes in potato and tomato minimize risk for oospore production in the presence of mating pairs of Phytophthora infestans. Eur. J. Plant Pathol. 2017, 149, 853-864. [CrossRef]

42. Ramakrishnan, A.P.; Ritland, C.E.; Blas Sevillano, R.H.; Riseman, A. Review of potato molecular markers to enhance trait selection. Am. J. Potato Res. 2015, 92, 455-472. [CrossRef]

43. Jansky, S.H.; Charkowski, A.O.; Douches, D.S.; Gusmini, G.; Richael, C.; Bethke, P.C.; Spooner, D.M.; Novy, R.G.; De Jong, H.; De Jong, W.S.; et al. Reinventing potato as a diploid inbred line-based crop. Crop Sci. 2016, 11, 1-11. [CrossRef]

44. Stokstad, E. The new potato. Science 2019, 363, 574-577. [CrossRef] [PubMed]

45. Lindhout, P.; Meijer, D.; Schotte, T.; Hutten, R.C.B.; Visser, R.G.F.; Van Eck, H.J.; Eck, H.J. Towards F1 hybrid seed potato breeding. Potato Res. 2011, 54, 301-312. [CrossRef]

46. Draffehn, A.M.; Meller, S.; Li, L.; Gebhardt, C. Natural diversity of potato (Solanum tuberosum) invertases. BMC Plant Biol. 2012, 10, 271. [CrossRef] [PubMed]

47. McCann, L.C.; Bethke, P.C.; Simon, P.W. Extensive variation in fried chip color and tuber composition in cold-stored tubers of wild potato (Solanum) germplasm. J. Agric. Food Chem. 2010, 58, 2368-2376. [CrossRef] [PubMed]

48. Jansky, S.H.; Hamernik, A.; Bethke, P.C. Germplasm release: Tetraploid clones with resistance to cold-induced sweetening. Am. J. Potato Res. 2011, 88, 218-225. [CrossRef]

49. Bhaskar, P.; Wu, L.; Busse, J.S.; Whitty, B.R.; Hamernik, A.J.; Jansky, S.H.; Buell, C.R.; Bethke, P.C.; Jiang, J. Suppression of the vacuolar invertase gene prevents cold-induced sweetening in potato. Plant Physiol. 2010, 154, 939-948. [CrossRef] [PubMed]

50. Hamernik, A.J.; Hanneman, R.E., Jr.; Jansky, S.H. Introgression of wild species germplasm with extreme resistance to cold sweetening into the cultivated potato. Crop Sci. 2009, 49, 529-542. [CrossRef]

51. Jansky, S.; Hamernik, A.; Chung, Y.S. M7 Germplasm Release: A tetraploid clone derived from Solanum infundibuliforme for use in expanding the germplasm base for french fry processing. Am. J. Potato Res. 2012, 89, 448-452. [CrossRef]

52. Hirsch, C.C.; Hirsch, C.D.; Felcher, K.; Coombs, J.; Zarka, D.; van Deynze, A.; de Jong, W.; Veilleux, R.E.; Jansky, S.; Bethke, P.; et al. Retrospective view of North American potato (Solanum tuberosum L.) breeding in the 20th and 21st centuries. G3 Genes Genomes Genet. 2013, 3, 1003-1013.

53. Endelman, J.B.; Carley, C.A.S.; Bethke, P.C.; Coombs, J.J.; Clough, M.E.; Da Silva, W.L.; De Jong, W.S.; Douches, D.S.; Frederick, C.M.; Haynes, K.G.; et al. Genetic variance partitioning and genome-wide prediction with allele dosage information in autotetraploid potato. Genetics 2018, 209, 77-87. [CrossRef] [PubMed]

54. Sverrisdóttir, E.; Byrne, S.; Sundmark, E.H.R.; Johnsen, H.Ø.; Kirk, H.G.; Asp, T.; Janss, L.; Nielsen, K.L. Genomic prediction of starch content and chipping quality in tetraploid potato using genotyping-by-sequencing. Theor. Appl. Genet. 2017, 130, 2091-2108. [CrossRef] [PubMed]

55. Hijmans, R.J.; Spooner, D.M. Geographic distribution of wild potato species. Am. J. Bot. 2001, 88, $2101-2112$. [CrossRef] [PubMed]

56. Hawkes, J.G.; Hjerting, J.P. The Potatoes of Argentina, Brazil, Paraguay, and Uruguay. A Biosystematic Study; Oxford University Press: Oxford, UK, 1969; p. 525.

57. Hijmans, R.J.; Spooner, D.M.; Salas, A.R.; Guarino, L.; de la Cruz, J. Atlas of Wild Potatoes; International Plant Genetic Resources Institute: Maccarese, Italy, 2002; p. 130.

58. Koenig, D.; Jiménez-Gómez, J.M.; Kimura, S.; Fulop, D.; Chitwood, D.H.; Headland, L.R.; Kumar, R.; Covington, M.F.; Devisetty, U.K.; Tat, A.V.; et al. Comparative transcriptomics reveals patterns of selection in domesticated and wild tomato. Proc. Natl. Acad. Sci. USA 2013, 110, E2655-E2662. [CrossRef] [PubMed] 
59. Hijmans, R.J. The effect of climate change on global potato production. Am. J. Potato Res. 2003, 80, 271-280. [CrossRef]

60. Slater, A.T.; Cogan, N.O.I.; Hayes, B.J.; Schultz, L.; Dale, M.F.B.; Bryan, G.J.; Forster, J.W. Improving breeding efficiency in potato using molecular and quantitative genetics. Theor. Appl. Genet. 2014, 127, 2279-2292. [CrossRef] [PubMed]

61. Annunziata, M.G.; Ciarmiello, L.F.; Woodrow, P.; Dell'Aversana, E.; Carillo, P. Spatial and temporal profile of glycine betaine accumulation in plants under abiotic stresses. Front. Plant Sci. 2019, 10, 1-13. [CrossRef]

62. Zhang, N.; Si, H.-J.; Wen, G.; Du, H.-H.; Liu, B.-L.; Wang, D. Enhanced drought and salinity tolerance in transgenic potato plants with a BADH gene from spinach. Plant Biotechnol. Rep. 2011, 5, 71-77. [CrossRef]

63. Zhu, M.; Meng, X.; Cai, J.; Li, G.; Dong, T.; Li, Z. Basic leucine zipper transcription factor SlbZIP1 mediates salt and drought stress tolerance in tomato. BMC Plant Biol. 2018, 18, 83. [CrossRef]

64. Navarre, D.A.; Brown, C.R.; Sathuvalli, V.R. Potato vitamins, minerals and phytonutrients from a plant biology perspective. Am. J. Potato Res. 2019, 96, 111-126. [CrossRef]

65. Bamberg, J.; Greenway, G. Nutritional and economic prospects for expanded potato outlets. Am. J. Potato Res. 2019, 96, 206-215. [CrossRef]

66. Hameed, A.; Zaidi, S.A.; Shakir, S.; Mansoor, S. Applications of new breeding technologies for potato improvement. Front. Plant Sci. 2018, 9, 1-15. [CrossRef]

67. Glendinning, D. Neo-Tuberosum: New potato breeding material. 3. Characteristics and variability of Neo-Tuberosum, and its potential value in breeding. Potato Res. 1975, 18, 351-362. [CrossRef]

68. Glendinning, D.R. Neo-Tuberosum: New potato breeding material. 1. The origin, composition, and development of the Tuberosum and Neo-Tuberosum gene pools. Potato Res. 1975, 18, 343-350. [CrossRef]

69. Glendinning, D.R. Neo-Tuberosum: New potato breeding material. 4. The breeding system of Neo-Tuberosum, and the structure and composition of the Neo-Tuberosum. Potato Res. 1976, 19, 27-36. [CrossRef]

70. Glendinning, D.R. Neo-Tuberosum: New potato breeding material. 2. A comparison of Neo-Tuberosum with unselected Andigena and Tuberosum. Potato Res. 1975, 18, 343-350. [CrossRef]

71. Munoz, F.J.; Plaisted, R. Yield and combining abilities in andigena potato after six cycles of recurrent phenotypic selection for adaptation to long day conditions. Am. J. Potato Res. 1981, 58, 469-479. [CrossRef]

72. Rasco, E.T.; Plaisted, R.L.; Ewing, E.E. Photoperiod response and earliness of S. tuberosum ssp. Andigena after six cycles of recurrent selection for adaptation to long days. Am. Potato J. 1980, 57, 435-447. [CrossRef]

73. Haynes, F. The use of cultivated diploid Solanum species in potato breeding. In Prospects for the Potato in the Developing World; French, E., Ed.; International Potato Center: Lima, Peru, 1972; pp. 100-110.

74. Carroll, C.P. A mass-selection method for the acclimatization and improvement of edible diploid potatoes in the United Kingdom. J. Agric. Sci. 1982, 99, 631-640. [CrossRef]

75. Tarn, T.R.; Tai, G.C.C. Tuberosum $x$ Tuberosum and Tuberosum $x$ Andigena potato hybrids: Comparisons of families and parents, and breeding strategies for Andigena potatoes in long-day temperate environments. Theor. Appl. Genet. 1983, 66, 87-91. [CrossRef]

76. Jansky, S.H.; Peloquin, S.J. Advantages of wild diploid Solanum species over cultivated diploid relatives in potato breeding programs. Genet. Resour. Crop Evol. 2005, 53, 669-674. [CrossRef]

77. Ross, H. The use of wild Solanum species in German potato breeding of the past and today. Am. Potato J. 1966, 43, 63-80. [CrossRef]

78. Morris, W.L.; Taylor, M.A. Improving flavor to increase consumption. Am. J. Potato Res. 2019, 96, $195-200$. [CrossRef]

79. Andre, C.M.; Ghislain, M.; Bertin, P.; Oufir, M.; Herrera, M.D.R.; Hoffmann, L.; Hausman, J.-F.; Larondelle, Y.; Evers, D. Andean potato cultivars (Solanum tuberosum L.) as a source of antioxidant and mineral micronutrients. J. Agric. Food Chem. 2007, 55, 366-378. [CrossRef]

80. De Haan, S.; Burgos, G.; Liria, R.; Rodriguez, F.; Creed-Kanashiro, H.M.; Bonierbale, M. The nutritional contribution of potato varietal diversity in Andean food systems: A case study. Am. J. Potato Res. 2019, 96, 151-163. [CrossRef]

81. Bevan, M.W.; Uauy, C.; Wulff, B.B.H.; Zhou, J.; Krasileva, K.; Clark, M.D. Genomic innovation for crop improvement. Nature 2017, 543, 346-354. [CrossRef] 
82. Uauy, C.; Wulff, B.B.H.; Dubcovsky, J. Combining traditional mutagenesis with new high-throughput sequencing and genome editing to reveal hidden variation in polyploid wheat. Annu. Rev. Genet. 2017, 51, 435-454. [CrossRef]

83. Tardivel, A.; Sonah, H.; Belzile, F.; O’Donoughue, L.S. Rapid identification of alleles at the soybean maturity gene $E 3$ using genotyping by sequencing and a haplotype-based approach. Plant Genome 2014, 7, 2. [CrossRef]

84. Ortiz, R.; Simon, P.; Jansky, S.; Stelly, D. Ploidy manipulation of the gametophyte, endosperm and sporophyte in nature and for crop improvement: A tribute to Professor Stanley J. Peloquin (1921-2008). Ann. Bot. 2009, 104, 795-807. [CrossRef]

85. Ortega, F.; Carrasco, A. Germplasm enhancement with wild tuber-bearing species: introgression of PVY resistance and high dry matter content from Solanum berthaultii, S. gourlayi, S. tarijense, and S. vernei. Potato Res. 2005, 48, 97-104. [CrossRef]

86. Camadro, E.L.; Erazzú, L.E.; Maune, J.F.; Bedogni, M.C. A genetic approach to the species problem in wild potato. Plant Biol. 2012, 14, 543-554. [CrossRef]

87. Hermsen, J.G.T. Introgression of genes from wild species, including molecular and cellular approaches. In Potato Genetics; Bradshaw, J.E., Mackay, G.R., Eds.; CAB International: Cambridge, UK, 1994; pp. 515-538.

88. Carputo, D.; Barone, A. Ploidy level manipulations in potato through sexual hybridisation. Ann. Appl. Biol. 2005, 146, 71-79. [CrossRef]

89. Bradshaw, J.E.; Ramsay, G. Utilisation of the Commonwealth Potato Collection in potato breeding. Euphytica 2005, 146, 9-19. [CrossRef]

90. Hanneman, R.E., Jr. The reproductive biology of the potato and its implications for breeding. Potato Res. 1999, 42, 283-312. [CrossRef]

91. Watanabe, K.; Orrillo, M.; Golmirzaie, A.M. Potato germplasm enhancement for resistance to biotic stresses at CIP. Conventional and biotechnology-assisted approaches using a wide range of Solanum species. Euphytica 1995, 85, 457-464. [CrossRef]

92. Jansky, S.H. Breeding, genetics, and cultivar development. In Advances in Potato Chemistry and Technology; Singh, J., Kaur, L., Eds.; Elsevier: Oxford, UK, 2009; pp. 27-61.

93. Xu, X.; Pan, S.; Cheng, S.; Zhang, B.; Mu, D.; Ni, P.; Zhang, G.; Yang, S.; Li, R.; Wang, G.; et al. Genome sequence and analysis of the tuber crop potato. Nature 2011, 475, 189-195.

94. Sato, S.; Tabata, S.; Hirakawa, H.; Asamizu, E.; Shirasawa, K.; Isobe, S.; Kaneko, T.; Nakamura, Y.; Shibata, D.; Aoki, K.; et al. The tomato genome sequence provides insights into fleshy fruit evolution. Nature 2012, 485, 635-641.

95. Liu, J.; Van Eck, J.; Cong, B.; Tanksley, S.D. A new class of regulatory genes underlying the cause of pear-shaped tomato fruit. Proc. Natl. Acad. Sci. USA 2002, 99, 13302-13306. [CrossRef]

96. Wu, S.; Zhang, B.; Keyhaninejad, N.; Rodríguez, G.R.; Kim, H.J.; Chakrabarti, M.; Illa-Berenguer, E.; Taitano, N.K.; Gonzalo, M.J.; Díaz, A.; et al. A common genetic mechanism underlies morphological diversity in fruits and other plant organs. Nat. Commun. 2018, 9, 1-12. [CrossRef]

97. Lippman, Z.B.; Semel, Y.; Zamir, D. An integrated view of quantitative trait variation using tomato interspecific introgression lines. Curr. Opin. Genet. Dev. 2007, 17, 545-552. [CrossRef]

98. Grube, R.; Radwanski, E.R.; Jahn, M. Comparative genetics of disease resistance within the Solanaceae. Genetics 2000, 155, 873-887.

99. Mazourek, M.; Cirulli, E.T.; Collier, S.M.; Landry, L.G.; Kang, B.-C.; Quirin, E.A.; Bradeen, J.M.; Moffett, P.; Jahn, M.M. The fractionated orthology of Bs2 and $R x / G p a 2$ supports shared synteny of disease resistance in the Solanaceae. Genetics 2009, 182, 1351-1364. [CrossRef]

100. Gebhardt, C.; Valkonen, J.P.T. Organization of genes controlling disease resistance in the potato genome. Annu. Rev. Phytopathol. 2001, 39, 79-102. [CrossRef]

101. Huang, S.; Van Der Vossen, E.A.; Kuang, H.; Vleeshouwers, V.G.; Zhang, N.; Borm, T.J.; Van Eck, H.J.; Baker, B.; Jacobsen, E.; Visser, R.G. Comparative genomics enabled the isolation of the R3a late blight resistance gene in potato. Plant J. 2005, 42, 251-261. [CrossRef]

102. Song, J.Q.; Bradeen, J.M.; Naess, S.K.; Raasch, J.A.; Wielgus, S.M.; Haberlach, G.T.; Liu, J.; Kuang, H.; Austin-Phillips, S.; Buell, C.R.; et al. Gene RB cloned from Solanum bulbocastanum confers broad spectrum resistance to potato late blight. Proc. Natl. Acad. Sci. USA 2003, 100, 9128-9133. [CrossRef] 
103. van der Vossen, E.; Sikkema, A.; Hekkert, B.T.L.; Gros, J.; Stevens, P.; Muskens, M.; Wouters, D.; Periera, A.; Stiekema, W.; Allefs, S. An ancient R gene from the wild potato species Solanum bulbocastanum confers broad-spectrum resistance to Phytophthora infestans in cultivated potato and tomato. Plant J. 2003, 36, 867-882. [CrossRef]

104. Hammond-Kosack, K.E.; Tang, S.; Harrison, K.; Jones, J.D.G. The tomato Cf-9 disease resistance gene functions in tobacco and potato to confer responsiveness to the fungal avirulence gene product Avr9. Plant Cell 2007, 10, 1251-1266. [CrossRef]

105. Cavatorta, J.; Perez, K.W.; Gray, S.M.; Van Eck, J.; Yeam, I.; Jahn, M. Engineering virus resistance using a modified potato gene. Plant Biotechnol. J. 2011, 9, 1014-1021. [CrossRef]

106. McCouch, S.R.; McNally, K.L.; Wang, W.; Sackville Hamilton, R. Genomics of gene banks: A case study in rice. Am. J. Bot. 2012, 99, 407-423. [CrossRef]

107. Camadro, E.L. Relevance of the genetic structure of natural populations, sampling and classification approaches for conservation and use of wild crop relatives: Potatoes as an example. Botany 2012, 90, 1065-1072. [CrossRef]

108. Leisner, C.P.; Hamilton, J.P.; Crisovan, E.; Manrique-Carpintero, N.C.; Marand, A.P.; Newton, L.; Pham, G.M.; Jiang, J.; Douches, D.S.; Jansky, S.H.; et al. Genome sequence of M6, a diploid inbred clone of the high glycoalkaloid-producing tuber-bearing potato species Solanum chacoense, reveals residual heterozygosity. Plant J. 2018, 94, 562-570. [CrossRef]

109. Aversano, R.; Contaldi, F.; Ercolano, M.R.; Grosso, V.; Iorizzo, M.; Tatino, F.; Xumerle, L.; Molin, A.D.; Avanzato, C.; Ferrarini, A.; et al. The Solanum commersonii genome sequence provides insights into adaptation to stress conditions and genome evolution of wild potato relatives. Plant Cell 2015, 27, 954-968. [CrossRef]

110. Aflitos, S.; Schijlen, E.; de Jong, H.; de Ridder, D.; Smit, S.; Finkers, R.; Wang, H.; Zhang, G.; Li, N.; Mao, L.; et al. Exploring genetic variation in the tomato (Solanum section Lycopersicon) clade by whole-genome sequencing. Plant J. 2014, 80, 136-148.

111. Van Treuren, R.; Magda, A.; Hoekstra, R.; Van Hintum, T.J.L. Genetic and economic aspects of marker-assisted reduction of redundancy from a wild potato germplasm collection. Genet. Resour. Crop Evol. 2004, 51, 277-290. [CrossRef]

112. McGregor, C.E.; Van Treuren, R.; Hoekstra, R.; Van Hintum, T.J.L. Analysis of the wild potato germplasm of the series Acaulia with AFLPs: Implications for ex situ conservation. Theor. Appl. Genet. 2002, 104, 146-156. [CrossRef]

113. Bryan, G.J.; McLean, K.; Waugh, R.; Spooner, D.M. Levels of intra-specific AFLP diversity in tuber-bearing potato species with different breeding systems and ploidy levels. Front. Genet. 2017, 8, 119. [CrossRef]

114. Bamberg, J.B.; Del Rio, A.H. Genetic heterogeneity estimated by RAPD Polymorphism of four tuber-bearing potato species differing by breeding system. Am. J. Potato Res. 2004, 81, 377-383. [CrossRef]

115. Bai, Y.; Lindhout, P. Domestication and breeding of tomatoes: What have we gained and what can we gain in the future? Ann. Bot. 2007, 100, 1085-1094. [CrossRef]

116. Hardigan, M.A.; Bamberg, J.; Buell, C.R.; Douches, D.S. Taxonomy and genetic differentiation among wild and cultivated germplasm of Solanum sect. Petota. Plant Genome 2015, 8, 1-16. [CrossRef]

117. Bedonni, M.C.; Camadro, E.L. Morphological and molecular evidence of natural interspecific hybridization in the diploid potato Solanum kurtizianum from Argentina. Botany 2009, 87, 78-87. [CrossRef]

118. Hawkes, J.G. Introgression in certain wild potato species. Euphytica 1962, 11, 26-35. [CrossRef]

119. Chung, Y.S.; Holmquist, K.; Spooner, D.M.; Jansky, S.H. A test of taxonomic and biogeographic predictivity: Resistance to soft rot in wild relatives of cultivated potato. Phytopathology 2011, 101, 205-212. [CrossRef]

120. Jansky, S.H.; Simon, R.; Spooner, D.M. A test of taxonomic predictivity: Resistance to the Colorado potato beetle in wild relatives of cultivated potato. J. Econ. Entomol. 2009, 102, 422-431. [CrossRef]

121. Jansky, S.H.; Simon, R.; Spooner, D.M. A test of taxonomic predictivity: Resistance to early blight in wild relatives of cultivated potato. Phytopathology 2008, 98, 680-687. [CrossRef]

122. Spooner, D.M.; Jansky, S.H.; Simon, R. Tests of taxonomic and biogeographic predictivity: Resistance to disease and insect pests in wild relatives of cultivated potato. Crop Sci. 2009, 49, 1367-1376. [CrossRef]

123. Jansky, S.H.; Simon, R.; Spooner, D.M. A test of taxonomic predictivity: Resistance to white mold in wild relatives of cultivated potato. Crop Sci. 2006, 46, 2561-2570. [CrossRef]

124. Cai, X.; Spooner, D.; Jansky, S. A test of taxonomic and biogeographic predictivity: Resistance to potato virus $\mathrm{Y}$ in wild relatives of the cultivated potato. Phytopathology 2011, 101, 1074-1080. [CrossRef] 
125. Khiutti, A.; Spooner, D.M.; Jansky, S.H.; Halterman, D.A. Testing taxonomic predictivity of foliar and tuber resistance to Phytophthora infestans in wild relatives of potato. Phytopathology 2015, 105, 1198-1205. [CrossRef]

126. Correll, D.S. The Potato and Its Wild Relatives; Texas Research Foundation: Renner, TX, USA, 1967; p. 606.

127. Vega, S.; Bamberg, J. Screening the U.S. potato collection for frost hardiness. Am. Potato J. 1995, 72, $13-21$. [CrossRef]

128. Khazaei, H.; Street, K.; Bari, A.; Mackay, M.; Stoddard, F.L. The FIGS (Focused Identification of Germplasm Strategy) approach identifies traits related to drought adaptation in Vicia faba genetic resources. PLoS ONE 2013, 8, e63107. [CrossRef]

129. Jansky, S.H.; Dawson, J.; Spooner, D.M. How do we address the disconnect between genetic and morphological diversity in germplasm collections? Am. J. Bot. 2015, 102, 1213-1215. [CrossRef]

130. Traini, A.; Iorizzo, M.; Mann, H.; Bradeen, J.M.; Carputo, D.; Frusciante, L.; Chiusano, M.L. Genome microscale heterogeneity among wild potatoes revealed by diversity arrays technology marker sequences. Int. J. Genom. 2013, 2013, 1-9. [CrossRef]

131. Van Weymers, P.S.M.; Baker, K.; Chen, X.; Harrower, B.; Cooke, D.E.L.; Gilroy, E.M.; Birch, P.R.J.; Thilliez, G.J.A.; Lees, A.K.; Lynott, J.S.; et al. Utilizing "Omic" technologies to identify and prioritize novel sources of resistance to the oomycete pathogen Phytophthora infestans in potato germplasm collections. Front. Plant Sci. 2016, 7, 672. [CrossRef]

132. Armstrong, M.R.; Vossen, J.; Lim, T.Y.; Hutten, R.C.B.; Xu, J.; Strachan, S.M.; Harrower, B.; Champouret, N.; Gilroy, E.M.; Hein, I. Tracking disease resistance deployment in potato breeding by enrichment sequencing. Plant Biotechnol. J. 2019, 17, 540-549. [CrossRef]

133. Chen, X.; Lewandowska, D.; Armstrong, M.R.; Baker, K.; Lim, T.-Y.; Bayer, M.; Harrower, B.; McLean, K.; Jupe, F.; Witek, K.; et al. Identification and rapid mapping of a gene conferring broad-spectrum late blight resistance in the diploid potato species Solanum verrucosum through DNA capture technologies. Theor. Appl. Genet. 2018, 131, 1287-1297. [CrossRef]

134. Tyler, B.M.; Tripathy, S.; Zhang, X.; Dehal, P.; Dehal, P.; Jiang, R.H.; Aerts, A.; Arredondo, F.D.; Baxter, L.; Bensasson, D.; et al. Phytophthora genome sequences uncover evolutionary origins and mechanisms of pathogenesis. Science 2006, 313, 1261-1267. [CrossRef]

135. Jiang, R.H.Y.; Tripathy, S.; Govers, F.; Tyler, B.M. RXLR effector reservoir in two Phytophthora species is dominated by a single rapidly evolving superfamily with more than 700 members. Proc. Natl. Acad. Sci. USA 2008, 105, 4874-4879. [CrossRef]

136. Haas, B.J.; Kamoun, S.; Zody, M.C.; Jiang, R.H.Y.; Handsaker, R.E.; Cano, L.M.; Grabherr, M.; Kodira, C.D.; Raffaele, S.; Torto-Alalibo, T.; et al. Genome sequence and analysis of the Irish potato famine pathogen Phytophthora infestans. Nature 2009, 461, 393-398. [CrossRef]

137. Vleeshouwers, V.G.; Rietman, H.; Krenek, P.; Champouret, N.; Young, C.; Oh, S.-K.; Wang, M.; Bouwmeester, K.; Vosman, B.; Visser, R.G.F.; et al. Effector genomics accelerates discovery and functional profiling of potato disease resistance and Phytophthora infestans avirulence genes. PLoS ONE 2008, 3, e2875. [CrossRef]

138. Ali, A.; Jansky, S. Fine screening for resistance to cold-induced sweetening in potato hybrids containing Solanum raphanifolium germplasm. Adv. Agric. 2015, 2015, 1-4.

139. Douches, D.S.; Bamberg, J.B.; Kirk, W.; Jastrzebski, K.; Niemira, B.A.; Coombs, J.; Bisognin, D.A.; Felcher, K.J. Evaluation of wild Solanum species for resistance to the US-8 genotype of Phytophthora infestans utilizing a fine-screening technique. Am. J. Potato Res. 2001, 78, 159-165. [CrossRef]

140. Bamberg, J.; Palta, J.; Peterson, L.; Martin, M.; Kreuger, A.R. Fine screening potato (Solanum) species germplasm for tuber calcium. Am. J. Potato Res. 1998, 75, 181-186. [CrossRef]

141. Bamberg, J.B.; Longtine, C.; Radcliffe, E.B. Fine screening Solanum (potato) germplasm accessions for resistance to Colorado potato beetle. Am. J. Potato Res. 1996, 73, 211-223. [CrossRef]

142. Ross, H. Potato Breeding_Problems and Perspectives; Verlag Paul Parey: Berlin, Germany, 1986; p. 132.

143. Tarn, T.R.; Tai, G.C.C.; de Jong, H.; Murphy, A.M.; Seabrook, J.E.A. Breeding potatoes for long-day, temperate climates. Plant Breed. Rev. 1992, 9, 217-232.

144. Bradshaw, J.E. Potato Breeding at the Scottish Plant Breeding Station and the Scottish Crop Research Institute: 1920-2008. Potato Res. 2009, 52, 141-172. [CrossRef]

145. Gopal, J. Challenges and way-forward in selection of superior parents, crosses and clones in potato breeding. Potato Res. 2015, 58, 165-188. [CrossRef] 
146. Allard, R.W. History of plant population genetics. Annu. Rev. Genet. 1999, 33, 1-27. [CrossRef]

147. Rieman, G.; Hooker, W.; Krantz, F.; Werner, H. Potato improvement through parental line breeding. Am. Potato J. 1956, 33, 319-323.

148. Krantz, F. Potato breeding methods III. A suggested procedure for potato breeding. Minn. Agric. Ext. Stn. Tech. Bull. 1924, 25, 3-32.

149. Chase, S. Analytic breeding in Solanum tuberosum L.-A scheme utilizing parthenotes and other diploid stocks. Can. J. Genet. Cytol. 1963, 5, 359-363. [CrossRef]

150. Marand, A.P.; Jansky, S.H.; Zhao, H.; Leisner, C.P.; Zhu, X.; Zeng, Z.; Crisovan, E.; Newton, L.; Hamernik, A.J.; Veilleux, R.E.; et al. Meiotic crossovers are associated with open chromatin and enriched with Stowaway transposons in potato. Genome Biol. 2017, 18, 203. [CrossRef]

151. Duan, H.; Richael, C.; Rommens, C.M. Overexpression of the wild potato eIF4E-1 variant Eva1 elicits Potato virus $Y$ resistance in plants silenced for native eIF4E-1. Transgenic Res. 2012, 21, 929-938. [CrossRef]

152. Arcibal, E.; Gold, K.M.; Flaherty, S.; Jiang, J.; Jahn, M.; Rakotondrafara, A.M. A mutant eIF4E confers resistance to potato virus $Y$ strains and is inherited in a dominant manner in the potato varieties Atlantic and Russet Norkotah. Am. J. Potato Res. 2016, 93, 64-71. [CrossRef]

153. Ghislain, M.; Byarugaba, A.A.; Magember, E.; Njoroge, A.; Rivera, C.; Roman, M.L.; Tovar, J.C.; Gamboa, S.; Forbers, G.A.; Kreuze, J.F.; et al. Stacking three late blight resistance genes from wild species directly into African highland potato varieties confers complete field resistance to local blight races. Plant Biotechnol. J. 2019, 17, 1119-1129. [CrossRef]

154. Clasen, B.M.; Stoddard, T.J.; Luo, S.; Demorest, A.L.; Li, J.; Cedrone, F.; Tibedu, R.; Davison, S.; Ray, E.E.; Daulhac, A.; et al. Improving cold storage and processing traits in potato through targeted gene knockout. Plant Biotechnol. J. 2016, 14, 169-176. [CrossRef]

155. Enciso-Rodriguez, F.; Manrique-Carpintero, N.C.; Nadakuduti, S.S.; Buell, C.R.; Zarka, D.; Douches, D. Overcoming self-incompatibility in diploid potato using CRISPR-Cas9. Front. Plant Sci. 2019, 10, 1-12. [CrossRef]

156. Collier, R.; Thomson, J.G.; Thilmony, R. A versatile and robust Agrobacterium-based gene stacking system generates high-quality transgenic Arabidopsis plants. Plant J. 2018, 95, 573-583. [CrossRef]

157. Zhu, X.; Richael, C.; Chamberlain, P.; Busse, J.S.; Bussan, A.J.; Jiang, J.; Bethke, P.C. Vacuolar invertase gene silencing in potato (Solanum tuberosum L.) improves processing quality by decreasing the frequency of sugar-end defects. PLoS ONE 2014, 9, e93381. [CrossRef]

158. Stich, B.; Van Inghelandt, D. Prospects and potential uses of genomic prediction of key performance traits in tetraploid potato. Front. Plant Sci. 2018, 9, 1-12. [CrossRef] 